\title{
Adequacy of the tetrazolium test to evaluate the viability of Jatropha curcas L. seeds ${ }^{1}$
}

\author{
Joyce de Oliveira Araújo² (D, Daniel Teixeira Pinheiro'* (D),Denise Cunha Fernandes \\ dos Santos Dias ${ }^{2}$ (D), Paulo César Hilst ${ }^{2}$ (iD, André Dantas de Medeiros ${ }^{2}$
}

\begin{abstract}
The tetrazolium test has been recommended for evaluating the viability of seeds with slow and ununiform germination, especially agroforestry species. The aim of this study was to propose a methodology to evaluate the viability of $J$. curcas L. seeds using the tetrazolium test and to generate visual aids to support the interpretation of the test. In the first trial, methods of seed preparation and staining were evaluated. The most promising methodologies were used to conduct the second test, which consisted of the evaluation of different concentrations $(0.10$ and $0.25 \%)$ and times ( 2 and $3 \mathrm{~h})$ of immersion of the seeds in the tetrazolium solution, using five lots. The seeds were analyzed individually and classified as viable or nonviable. At the same time, germination, first count, emergence and seedling emergence speed index tests were conducted. The tetrazolium test is efficient for evaluating the viability of seeds of J. curcas L. providing results correlated with germination and seedling emergence. Pre-soaked seeds should have their integument removed and then sectioned longitudinally and medially lengthwise for immersion in $0.10 \%$ solution of 2,3,5-triphenyl chloride tetrazolium for three hours at $35^{\circ} \mathrm{C}$.
\end{abstract}

Index terms: Jatropha curcas L., physic nut, methodology, physiological quality.

\section{Adequação do teste de tetrazólio para avaliação da viabilidade de sementes de Jatropha curcas L.}

\begin{abstract}
RESUMO - O teste de tetrazólio tem sido recomendado para a avaliação da viabilidade de sementes que apresentam germinação lenta e desuniforme, especialmente espécies agroflorestais. O objetivo do trabalho foi propor uma metodologia para avaliação da viabilidade das sementes de $J$. curcas L. pelo teste de tetrazólio e gerar recursos visuais que auxiliem na interpretação do teste. Nesta pesquisa foram realizados dois ensaios. No primeiro ensaio, foram avaliados métodos de preparo e coloração das sementes. As metodologias mais promissoras foram utilizadas na condução do segundo ensaio, que consistiu na avaliação de diferentes concentrações $(0,10$ e $0,25 \%)$ e tempos $(2$ e $3 \mathrm{~h})$ de imersão das sementes na solução de tetrazólio, utilizando-se cinco lotes. As sementes foram analisadas individualmente e classificadas como viáveis ou não viáveis. Paralelamente, foram conduzidos testes de germinação, primeira contagem, emergência e índice de velocidade de emergência de plântulas. O teste de tetrazólio é eficiente para a avaliação da viabilidade de sementes de $J$. curcas L. fornecendo resultados correlacionados com a germinação e a emergência de plântulas. Sementes pré-embebidas devem ter o tegumento removido e, em seguida, seccionadas longitudinal e medianamente no sentido do comprimento para imersão em solução de cloreto 2,3,5-trifenil tetrazólio a $0,10 \%$ por três horas a $35^{\circ} \mathrm{C}$.
\end{abstract}

Termos para indexação: Jatropha curcas L., pinhão-manso, metodologia, qualidade fisiológica.

\section{Introduction}

The species Jatropha curcas L., known as physic nut, is an oilseed from the family Euforbiaceae. In addition to a high oil content in its seeds (30-40\%), the species has high yield and other characteristics considered as essential for biodiesel production (Gübitz et al., 1999; Pompelli et al., 2010; Mofijur et al., 2013). Recent studies have reported that

${ }^{1}$ Submitted on: 4/30/2019. Accepted on: 9/19/2019.

${ }^{2}$ Departamento de Agronomia, Universidade Federal de Viçosa - Viçosa, MG, Brasil.

*Corresponding author: <pinheiroagroufv@gmail.com> 
the species also has potential for production of anti-fungal plant extracts (Cordova-Albores et al., 2016; Hu et al., 2019; Rampadarath et al., 2016).

Propagation of the species occurs mainly by seeds, which have irregular germination, attributed to factors such as genotype, integument resistance to water absorption and sensitivity to deterioration during storage (Oliveira et al., 2014). According to these authors, at the end of the germination test with seeds of this species, there is a significant proportion of unimbibed seeds as well as imbibed and non-germinated seeds which may or may not be dead. According to Kak et al. (2009), the seeds take fourteen to twenty days to germinate under ideal laboratory conditions, and they are dormant when newly harvested.

The tetrazolium test is widely used to estimate seed viability of several species. Also, it is an alternative for species whose seeds have dormancy or slow germination, especially native and forest species (Lamarca and Barbedo, 2014). It has also been used efficiently in seeds from agricultural crops such as soybean (Pereira et al., 2019), chickpeas (Paraíso et al., 2019), beans (Bhering et al., 1999), cotton (Santos et al., 1992), corn (Chamma and Novembre, 2007), coffee (Dias and Silva, 1986) and barley (Grzybowski et al., 2012). In forage species such as Brachiaria spp. and Panicum spp., the results of the tetrazolium test have been used as a basis for seed marketing (MAPA, 2016).

The tetrazolium test is based on staining of seed tissues, resulting from the reaction of dehydrogenase enzymes with tetrazolium salt to form a non-diffusible red-colored compound called formazan (França-Neto et al., 1999). The differences in staining enable a distinction between lived, deteriorated and dead tissues, and the classification of seeds into viable or non-viable (Brasil, 2009). The main advantages of this test are the speed and efficacy of providing the results. Moreover, in some cases, the test allows the diagnosis of the causes of reduction of the physiological potential of seeds, as reported for soybean (França-Neto et al., 1999).

However, the efficiency of the tetrazolium test for evaluation of seed viability depends on the development of an appropriate method for each species, which involves the definition of appropriate conditions for preconditioning, seed preparation, staining and evaluation. In seeds of $J$. curcas, Pinto et al. (2009) found that seed prehydration, followed by integument removal and immersion in $0.50 \%$ tetrazolium solution for two hours at $40{ }^{\circ} \mathrm{C}$, was efficient to evaluate viability. Brenha et al. (2012) and Schulz et al. (2012), using this same concentration and temperature, recommend a period of six and four hours, respectively, for proper staining of seed tissues. In their turn, Kak et al. (2009) found that staining occurred when seeds that had been previously soaked in water for $17 \mathrm{~h}$ were immersed in a tetrazolium solution at $0.10 \%$ for six hours at $30{ }^{\circ} \mathrm{C}$ or at $0.25 \%$ at $40{ }^{\circ} \mathrm{C}$ for four hours.

Importantly, most of these studies with $J$. curcas did not use seed lots with different levels of physiological quality in order to relate the results of the tetrazolium test with those of other tests, such as germination and seedling emergence. Moreover, as this is a test whose result is based on the observation of color and the visual analysis of tissues, it is not enough to illustrate only one colored seed as viable and one colorless seed as non-viable. Possible staining patterns, location and extent of damage should be illustrated for a safe and efficient interpretation of results.

Thus, the aim of this research was to propose a methodology for conducting the tetrazolium test and to verify the efficiency of the test in evaluating the viability of $J$. curcas seeds, producing images that can help the interpretation of the results.

\section{Material and Methods}

This research was carried out at the Seed Testing Laboratory, Department of Plant Science, Universidade Federal de Viçosa. Two assays were conducted.

Assay 1

First, seeds from one lot of J. curcas were pre-conditioned on paper towels previously moistened with a volume of water equivalent to 2.7 times the weight $(\mathrm{g})$ of the dry paper and kept in a germinator at $25{ }^{\circ} \mathrm{C}$ for sixteen hours, when the seeds reached $40 \%$ moisture content. This time was defined based on the soaking curve, defined in preliminary tests.

Then, the seeds were prepared for staining, using two replications of 25 seeds. To this end, the integument was removed with the aid of a stylus to avoid damage to the endosperm. Whole seeds (without the integument) and seeds sectioned longitudinally and medially lengthwise through the endosperm and embryo were completely immersed in 2,3,5-triphenyl tetrazolium chloride solution at concentrations of $0.10 \%, 0.25 \%$, $0.50 \%$ and $0.75 \%$ and kept in a BOD chamber at $35{ }^{\circ} \mathrm{C}$ and $40{ }^{\circ} \mathrm{C}$ in the dark. Every hour, intensity of seed tissue staining was observed for four hours to determine the most appropriate time for obtaining a bright pink color, which is considered to be adequate for interpreting the test. After each period, the whole seeds were sectioned longitudinally and medially as described above.

Assay 2

Five seed lots were used to evaluate the most appropriate seed staining method, based on the results of the first assay.

The seeds from each lot, in four replications of 25 , 
were preconditioned for hydration and the integument was removed, as reported in assay 1 . Then, the seeds were sectioned longitudinally and medially as described in assay 1 , with selection of the half that allowed better visualization of the internal structures of each seed. The samples were placed in plastic cups and immersed in tetrazolium solution at concentrations of $0.10 \%$ and $0.25 \%$ and left for two, three and four hours in a BOD incubator at $35^{\circ} \mathrm{C}$ in the dark. Only one half of each seed was considered for evaluation, as the first test showed a similar staining pattern of the two halves of the seeds (Figure 1).

The seeds were evaluated individually in order to identify tissue alterations that would enable the classification of viability based on the tetrazolium test. Each seed was classified as viable or non-viable according to tissue staining intensity for the embryo and the endosperm, considering the presence, location and extent of damage, as well as tissue texture. Therefore, the recommendations of the Rules for Seed Testing (Brasil, 2009) and the parameters established by GasparOliveira et al. (2009) were employed for the tetrazolium test in castor seeds, and the necessary adaptations were made for the seeds of $J$. curcas. The seeds were then classified as viable or non-viable according to the criteria described below.

Viable seeds: embryo and endosperm with a pink stain color all over, with normal-looking tissues; bright red embryonic axis with pink endosperm; endosperm and/or cotyledons showing less than $50 \%$ of white, brown or bright red area in a region not too close to the embryonic axis (Figure 2).

Non-viable seeds: embryonic axis completely white or with white spots on the root and/or hypocotyl; endosperm and cotyledons presenting more than $50 \%$ of damaged area, characterized by white or brown tissue (with stink bug) or with an intense red color and a flabby texture; white, brown or deep red lesions with flaccid tissue in the embryonic axisendosperm attachment region (Figure 3).

The seeds of each lot were treated with the fungicide Derosal Plus ${ }^{\circledR}$ at a rate of $60 \mathrm{~mL} .100 \mathrm{~kg}^{-1}$ seed, and they were evaluated by the following tests:

Moisture content: determined by the oven method at $105 \pm 3^{\circ} \mathrm{C}$ for 24 hours (Brasil, 2009). Four replications of 25 seeds were used for each lot, and the results were expressed as percentage on a wet basis.

Germination: the seeds, in eight replications of 25, were distributed on two sheets of paper previously moistened with an equivalent amount of water 2.7 times the weight of the dry paper. Rolls were prepared and kept in a germinator at $25^{\circ} \mathrm{C}$. Evaluations were performed at seven and twelve days after sowing. Every two replications in the germination test were joined (two by two) to obtain four replications and calculate

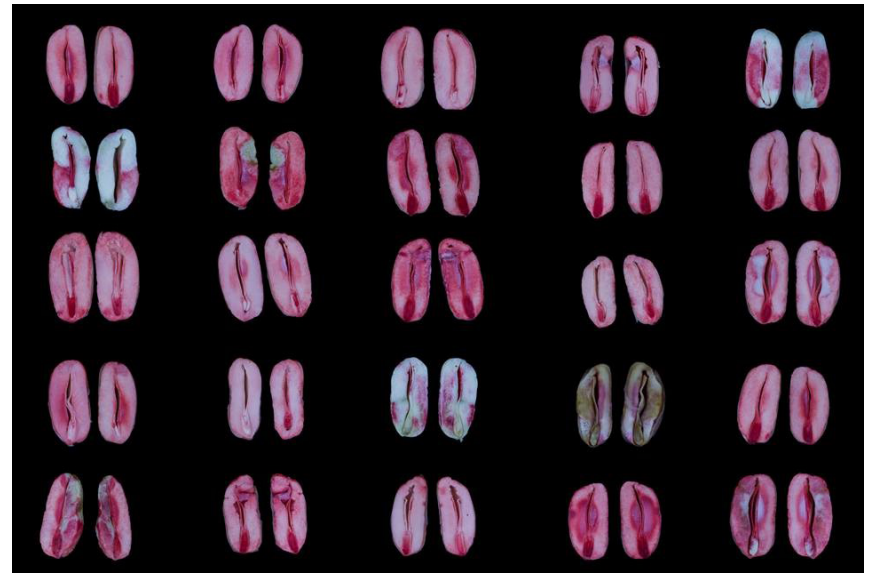

Figure 1. J.curcas L. seeds sectioned longitudinally and medially lengthwise, through the endosperm and embryo, after immersion in tetrazolium solution. Staining and damage were symmetrical between the halves.

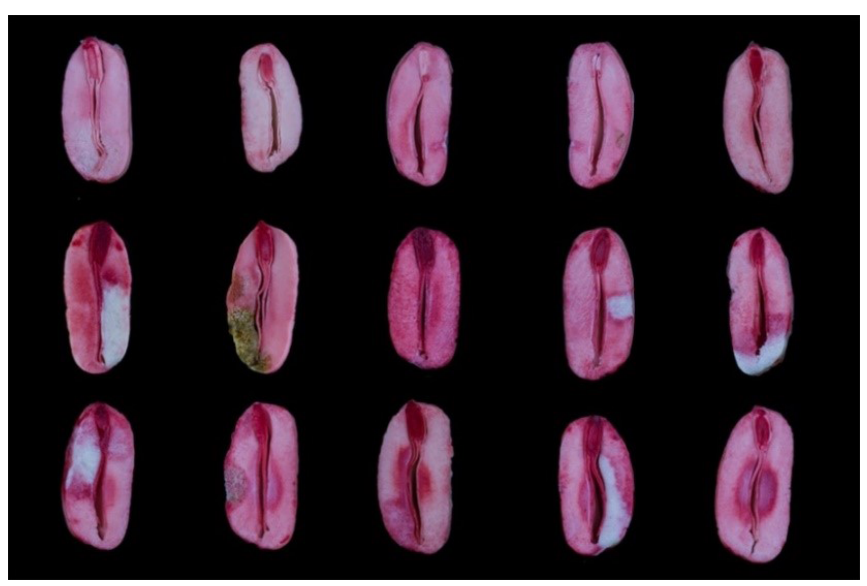

Figure 2. J. curcas seeds classified as viable according to the evaluation criteria described above.

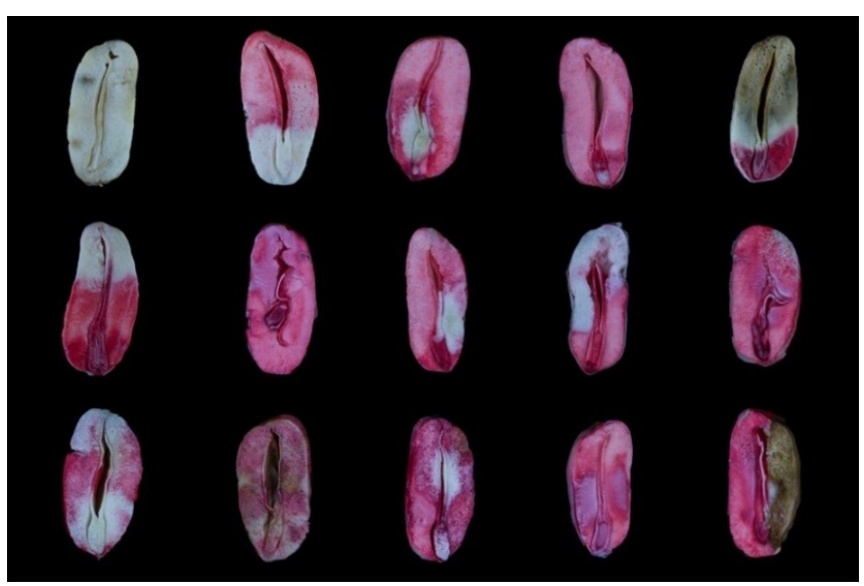

Figure 3. J. curcas seeds classified as non-viable according to the evaluation criteria described above. 
the germination percentage. The results were expressed as percentage of normal seedlings (Oliveira et al., 2014).

First germination count: it consisted of the percentage of normal seedlings determined on the seventh day after the beginning of the germination test (Oliveira et al., 2014).

Seedling emergence: it was conducted in a greenhouse using plastic trays $(32.5 \mathrm{~cm} \times 53.5 \mathrm{~cm} \times 13.5 \mathrm{~cm})$ containing sand as substrate. Sowing was performed at the depth of $2 \mathrm{~cm}$ and the substrate was irrigated daily. Four replicates of fifty seeds were used, and the seedlings were considered emerged when their endosperm was above the substrate surface. Daily counts were made until stand stabilization, and the results were expressed as percentage of emerged seedlings.

Emergence speed index: it was calculated using data collected from daily counts of the seedling emergence test, according to Maguire (1962).

Experimental design and statistical analysis: the experimental design was completely randomized with four replications. For the germination data, the 25 -seed replications were added two by two to obtain four replications of fifty seeds. The data underwent analysis of variance (ANOVA). After confirmation of normal distribution of errors by the Shapiro-Wilk test and homogeneity of variances by the Bartlett test, the means were compared by Tukey's test at $5 \%$ probability. In addition, a multivariate principal component analysis (PCA) was performed and Pearson's simple correlation coefficients ( $r$ ) were calculated for all combinations between the tetrazolium test and the other tests performed. The significance of $r$ values was determined by the test at $5 \%$ probability.

\section{Results and Discussion}

In assay 1 , it was found that sectioning seeds longitudinally (Figure 4A) prior to immersion in the tetrazolium solution was more suitable for internal tissue staining than immersion of the whole seeds (without the integument) in the solution (Figure 4B).

In the whole seeds, there was no adequate diffusion of the tetrazolium solution to the internal tissues of the endosperm, whose stain color remained similar to their original one. Therefore, the results were difficult to interpret. It is noted that the embryonic axis of these seeds was pink in the inside in most seeds analyzed, regardless of the solution concentration, probably because of the higher metabolic activity of the cells compared to the endosperm (Figure 4) (Peters, 2000).

In assay 1 , it was found that at the highest concentrations tested $(0.50$ and $0.75 \%$ ), there was a development of more intense red color at all staining times (Figures 5 and 6), making it difficult to distinguish between viable and deteriorated tissues. Brenha et al. (2012) also found that these concentrations intensely stained the seed structures of $J$. curcas, making it difficult to differentiate more vigorous tissues from those in the process of deterioration.

In addition to requiring higher amounts of tetrazolium salt, the more intense color found at these concentrations may make it difficult to distinguish between pink (viable) and deep red (deteriorated) tissues, which could affect the achievement of consistent results. Therefore, such concentrations were not used in test 2 .

Regarding the temperatures tested for staining, there was greater color intensity in the seed tissues at $40{ }^{\circ} \mathrm{C}$ compared to $35^{\circ} \mathrm{C}$. The use of higher temperatures during seed staining accelerates their seed metabolism and enzyme system

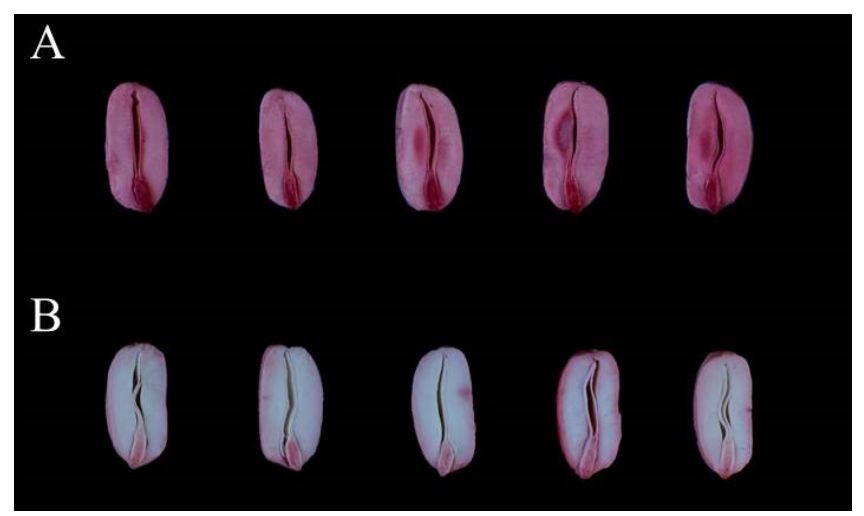

Figure 4. Stained after immersion in a $0.10 \%$ tetrazolium solution for $3 \mathrm{~h}$. Seeds sectioned lengthwise prior to immersion in the solution (A) and whole seeds immersed in the solution, and sectioned later (B).
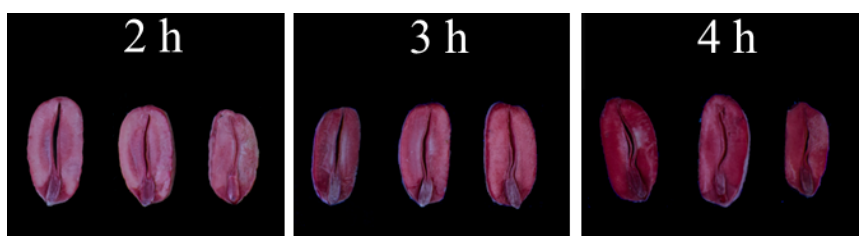

Figure 5. J. curcas seeds stained after immersion in a $0.50 \%$ tetrazolium solution for 2, 3 and $4 \mathrm{~h}$.
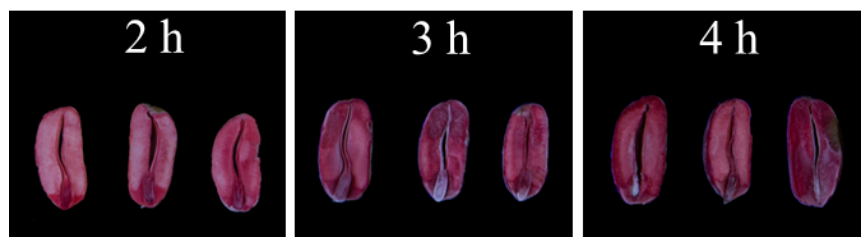

Figure 6. J. curcas seeds stained after immersion in a $0.75 \%$ tetrazolium solution for 2, 3 and $4 \mathrm{~h}$. 
activation, allowing for faster and more intense staining (Grabe, 1976). However, it should be noted that the sharpness and ease of differentiation of the tones in the seed tissues occurred more appropriately at $35^{\circ} \mathrm{C}$. Hence this temperature was used in test 2 .

In assay 2, the use of solutions at concentrations of 0.10 and $0.25 \%$ generally resulted in a light pink stain color in the seeds without damage or injury - which was indicative of viable and vigorous tissue - and in an intense red color in deteriorated tissues (Figures 7 and 8). For this reason, these concentrations were used for a more accurate assessment. Kak et al. (2009) found adequate staining with the immersion of seeds in a tetrazolium solution at these two concentrations. It was also found that, at these concentrations, the one-hour staining period did not allow the development of adequate staining in the tissues. Thus, periods of two, three and four hours were used in assay 2.

Both tetrazolium solution concentration and seed immersion time in the solution were found to be important to achieve adequate color development in the tissues, i.e., compatible with their physiological state, whether viable, deteriorated or dead.

In the $0.10 \%$ solution in the two-hours period, the pink color of the viable tissues was slightly lighter and less clear when compared to the other exposure times (three and four hours) (Figure 7).

At this same concentration, the pink color found at three and four hours was similar to the one obtained in the $0.25 \%$ solution for two hours (Figure 8), in which the pink color was considered to be ideal for the characterization of viable tissues. This was not so evident at a concentration of $0.10 \%$ for two hours and slightly less intense than at $0.10 \%$ for three and four hours (Figures 7 and 8).

In general, the colors observed in the three- and four-hours periods were similar (Figures 7 and 8). Because it is a rapid test, a decision was made not to use the four-hours period and to define the two and three hours times in the concentrations of 0.10 and $0.25 \%$ as potential procedures to obtain a more uniform color of the internal tissues of the seeds, allowing a clear distinction between viable (pink), deteriorated (deep red) and dead (milky white) tissues.

According to Brenha et al. (2012), the immersion of $J$. curcas seeds in a $0.25 \%$ tetrazolium solution for four hours allowed clearer visualization of the living tissues of the embryo. For these authors, the time of two hours was not enough to stain the living structures of the seeds at all study concentrations. On the other hand, Dantas et al. (2009) found that the use of $0.10 \%$ solution for two hours at $30^{\circ} \mathrm{C}$ was enough to allow the evaluation of the viability of $J$. curcas.

Figures 5 and 8 show that the reddish hue of viable and non-viable tissues was less distinct in the $0.25 \%$ solution at longer times (three and four hours), and it was similar to staining obtained at $0.5 \%$ for two hours. This result reinforces the recommendation of using 0.10 or $0.25 \%$ concentrations for adequate staining of $J$. curcas seeds in the tetrazolium test.

As previously mentioned, different methodologies have already been cited as suitable for tetrazolium testing in $J$. curcas seeds (Brenha et al., 2012; Kak et al., 2009; Pinto et al., 2009; Schulz et al., 2012). However, few studies have applied the most promising methods to seeds from lots with different levels of physiological quality, or compared the results found in the tetrazolium test with those of other recommended seed quality tests.

Therefore, seeds from lots with different quality levels were used, with water content ranging from 8.3 to $9 \%$. In the characterization of the lots, it was generally found that germination, emergence and ESI of the seeds of lots 2 and 4 were similar and higher than the values found for the other lots. It was also found that lot 5 was inferior to the others in most of the applied tests (Table 1).

Among the procedures evaluated for the tetrazolium test, when the concentration of $0.25 \%$ for $2 \mathrm{~h}$ (TZ3) was used, only lot 5 could be distinguished as significantly inferior to the others. The other treatments (TZ1, TZ2 and TZ4) allowed a more efficient distinction between lots as to viability, similarly to the germination and vigor tests (Table 1). In castor seeds, Gaspar-Oliveira et al. (2011) found that the tetrazolium test did not allow the classification of the lots into vigor levels, and the results could not be related to seedling emergence in the field. However, there was agreement between the results found in the germination test and those of the tetrazolium test regarding the classification of lots into quality levels.

Principal component analysis (PCA) shows that components
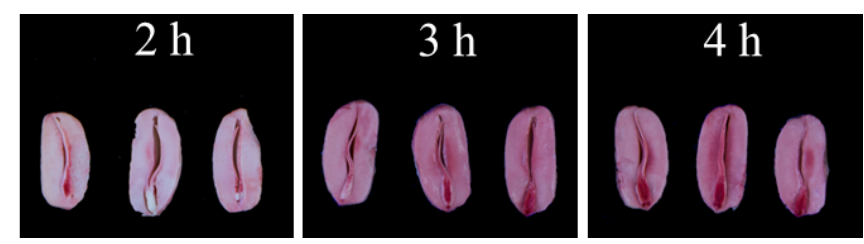

Figure 7. J. curcas seeds stained after immersion in a $0.10 \%$ tetrazolium solution for 2, 3 and $4 \mathrm{~h}$.
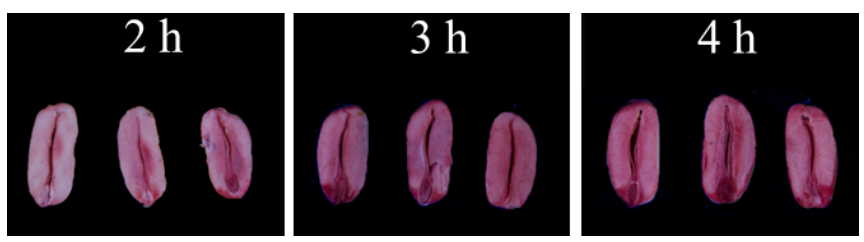

Figure 8. J. curcas seeds stained after immersion in a $0.25 \%$ tetrazolium solution for 2, 3 and $4 \mathrm{~h}$. 
1 (PC1) and 2 (PC2), respectively, accounted for 95.3 and 3.2\% of the total data variability, in a total of $98.5 \%$ (Figure 9).

Medeiros et al. (2018) stated that principal component analysis can be used to interpret seed quality-related variables. In this context, the germination vector (blue color) and vigor vectors (green color) were in the positive scores of PC1, as well as the viability vectors determined by the tetrazolium test (red color) (Figure 9). These observations indicate a positive correlation between these parameters, considering that PC1 explained almost all of the data variability, which was evidenced by the correlation analysis (Table 2). These results generally highlight the efficiency of the methodologies tested for the tetrazolium test in comparison to other physiological quality evaluation tests, such as germination and seedling emergence.

PCA also helped to distinguish the lots used, since lots 2 and 4 are located close to the quality vectors, lots 1 and 3 are in an intermediate position, and lot 5 is further away (Figure 9), confirming the classification of lots obtained by the means comparison tests (Table 1).

In the simple correlation analysis, it was found that the viability obtained by the tetrazolium test correlated significantly with germination, first count, percentage of seedling emergence and seedling emergence speed index (Table 2).

Similar results were found in castor seeds: where there

Table 1. Characterization of initial quality of seed lots of J. curcas L.: moisture content (MC), germination (G), first germination count (FGC), seedling emergence (E), emergence speed index (ESI), viability by the tetrazolium test at $0.10 \%$ for 2 $\mathrm{h}$ (TZ1), $0.10 \%$ for $3 \mathrm{~h}$ (TZ2), $0.25 \%$ for $2 \mathrm{~h}$ (TZ3) and $0.25 \%$ for $3 \mathrm{~h}$ (TZ4).

\begin{tabular}{cccccccccc}
\hline Lots & MC (\%) & G (\%) & FGC (\%) & E (\%) & $\begin{array}{c}\text { ESI } \\
\left.\text { (seedling.day }{ }^{-1}\right)\end{array}$ & $\begin{array}{c}\text { TZ1 } \\
(\%)\end{array}$ & TZ2 (\%) & TZ3 (\%) & TZ4 (\%) \\
\hline 1 & 9.0 & $83.5 \mathrm{~b}$ & $73.5 \mathrm{bc}$ & $84.5 \mathrm{~b}$ & $5.49 \mathrm{~b}$ & $88 \mathrm{a}$ & $86 \mathrm{~b}$ & $87 \mathrm{a}$ & $88 \mathrm{ab}$ \\
2 & 8.5 & $93.5 \mathrm{a}$ & $89.5 \mathrm{a}$ & $94.5 \mathrm{a}$ & $6.30 \mathrm{a}$ & $95 \mathrm{a}$ & $95 \mathrm{a}$ & $92 \mathrm{a}$ & $95 \mathrm{a}$ \\
3 & 8.2 & $87.5 \mathrm{ab}$ & $80.0 \mathrm{ab}$ & $85.5 \mathrm{~b}$ & $4.70 \mathrm{c}$ & $84 \mathrm{ab}$ & $80 \mathrm{~b}$ & $81 \mathrm{a}$ & $81 \mathrm{~b}$ \\
4 & 8.3 & $93.5 \mathrm{a}$ & $85.5 \mathrm{ab}$ & $98.0 \mathrm{a}$ & $6.12 \mathrm{a}$ & $95 \mathrm{a}$ & $95 \mathrm{a}$ & $91 \mathrm{a}$ & $95 \mathrm{a}$ \\
5 & 9.0 & $70.0 \mathrm{c}$ & $61.0 \mathrm{c}$ & $75.5 \mathrm{c}$ & $4.14 \mathrm{~d}$ & $73 \mathrm{~b}$ & $72 \mathrm{c}$ & $67 \mathrm{~b}$ & $70 \mathrm{c}$ \\
$\mathrm{F}$ & - & $19.32^{*}$ & $13.13^{*}$ & $51.55^{*}$ & $64.58^{*}$ & $8.63^{*}$ & $43.36^{*}$ & $15.72^{*}$ & $18.01^{*}$ \\
\hline $\mathrm{CV}(\%)$ & - & 5.15 & 7.93 & 2.83 & 4.29 & 7.15 & 3.52 & 6.18 & 5.8 \\
\hline
\end{tabular}

*Significant by the F-test at $5 \%$ probability; $\mathrm{F}=\mathrm{F}$-test; $\mathrm{CV}=$ coefficient of variation.

*Means followed by the same letter in the column do not differ statistically by Tukey's test at $5 \%$ probability.

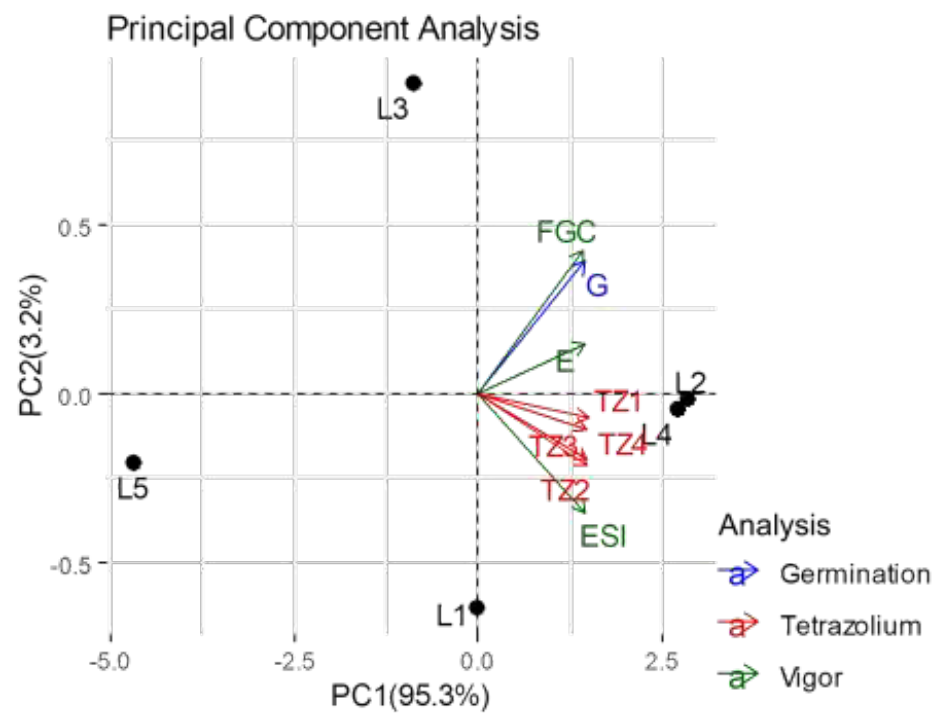

PC1: principal component 1; PC2: principal component 2; G: germination; FGC: first germination count; E: emergence; ESI: emergence speed index; TZ1: $0.10 \%$ for $2 \mathrm{~h}$; TZ2: $0.10 \%$ for $3 \mathrm{~h}$; TZ3: $0.25 \%$ for $2 \mathrm{~h}$; TZ4: $0.25 \%$ for 3h; L1: Lot 1; L2: Lot 2; L3: Lot 3; L4: Lot 4; L5: Lot 5.

Figure 9. Biplot obtained by the linear combination of the physiological quality variables of five seed lots of $J$. curcas. 
Table 2. Pearson's simple correlation coefficients (r) estimated among germination variables (G), first germination count (FGC), seedling emergence (E), emergence speed index (ESI), viability by the tetrazolium test at $0.10 \%$ for $2 \mathrm{~h}$ (TZ1); $0.10 \%$ for 3 hours (TZ2); $0.25 \%$ for $2 \mathrm{~h}$ (TZ3); and $0.25 \%$ for $3 \mathrm{~h}$ (TZ4).

\begin{tabular}{|c|c|c|c|c|c|c|c|c|}
\hline & FGC & G & $\mathrm{E}$ & ESI & TZ1 & TZ2 & TZ3 & TZ4 \\
\hline FGC & & $0.94 * *$ & $0.75^{* *}$ & $0.68 * *$ & $0.71 * *$ & 0.80 ** & $0.66^{*}$ & $0.69^{* *}$ \\
\hline $\mathrm{G}$ & & & $0.82^{* *}$ & $0.74 * *$ & $0.72 * *$ & $0.87^{* *}$ & $0.80^{* *}$ & $0.72^{* *}$ \\
\hline E & & & & $0.91 * *$ & $0.73 * *$ & $0.90 * *$ & $0.78 * *$ & $0.81^{* *}$ \\
\hline ESI & & & & & $0.80^{* *}$ & $0.94^{* *}$ & $0.84^{* *}$ & $0.87^{* *}$ \\
\hline $\mathrm{TZ1}$ & & & & & & $0.73 * *$ & $0.78 * *$ & $0.79 * *$ \\
\hline TZ2 & & & & & & & $0.86^{* *}$ & $0.85^{* *}$ \\
\hline $\mathrm{TZ3}$ & & & & & & & & $0.82^{* *}$ \\
\hline TZ4 & & & & & & & & \\
\hline
\end{tabular}

**: significant at $1 \%$ probability by the T-test.

was a correlation between the results of the tetrazolium and sand germination, field emergence, seedling length and seedling dry weight tests (Gaspar-Oliveira et al. 2011).

In summary, based on Pearson's correlation analysis (Table 2), it was possible to confirm the results found in the characterization of the lots (Table 1) and in the PCA (Figure 9), since significant correlations were found between the variables generated by the germination and emergence tests, and the results found in the methodologies tested for the tetrazolium tests.

Based on these results, it can be stated that the methodologies tested for the tetrazolium test were efficient in evaluating the viability of $J$. curcas seeds. Since the concentration of $0.10 \%$ did not differ from that of $0.25 \%$, and concentrations of 0.50 and $0.75 \%$ were not suitable for seed staining as they made it difficult to distinguish between viable and deteriorated tissues, one recommends the use of the lower concentration $(0.10 \%)$, because it would require lesser use of tetrazolium salt to conduct the test, thereby making the test more economical. Kak et al. (2009) found adequate staining after immersion of the seeds in a $0.10 \%$ or $0.25 \%$ tetrazolium solution. Previous studies conducted in Brazil with seeds of $J$. curcas had indicated a concentration of $0.50 \%$ (Pinto et al., 2009; Brenha et al., 2012), although the latter authors referred to the excessive staining promoted by the concentration of $0.50 \%$ in comparison to $0.25 \%$. Importantly, in all these studies mentioned above, no different lots were used to validate the results of the tetrazolium test, and they were compared to those obtained in other physiological quality evaluation tests.

Regarding the immersion times of seeds in a tetrazolium solution at a concentration of $0.10 \%$, the results found in all tested times showed a significant correlation with those of the other quality tests, during the staining period. However, the highest correlation coefficients were found at the three-hours staining period $(\mathrm{TZ2})(\mathrm{r}=0.97$ with the germination test $; \mathrm{r}=0.80$ with the first germination count, $r=0.90$ with seedling emergence and $r=0.94$ with ESI) (Table 2). Kak et al. (2009) recommended the immersion of seeds in a $0.10 \%$ tetrazolium solution for six hours at $30^{\circ} \mathrm{C}$. In the present work, using the temperature of $35^{\circ} \mathrm{C}$ reduced the time to obtain the results to three hours.

\section{Conclusions}

The tetrazolium test can be used for evaluation of seed viability of $J$. curcas L. providing results correlated with germination and seedling emergence.

For tetrazolium test, pre-soaked seeds should have their integument removed and then be sectioned longitudinally and medially lengthwise for immersion in $0.10 \% 2,3,5$-triphenyl tetrazolium chloride solution during three hours at $35^{\circ} \mathrm{C}$.

\section{References}

BHERING, M.C.; SILVA, R.D.; ALVARENGA, E.M.; DIAS, D.C.F.S.; PENA, M.F. Metodologia do teste de tetrazólio em sementes de feijão. In: ABRATES (ed.). Vigor de sementes: conceitos e testes. Londrina: ABRATES, 1999.

BRASIL. Ministério da Agricultura, Pecuária e Abastecimento. Regras para análise de sementes. Ministério da Agricultura, Pecuária e Abastecimento. Secretaria de Defesa Agropecuária. Brasília: MAPA/ACS, 2009. 395p. http://www.agricultura.gov.br/assuntos/ insumos-agropecuarios/arquivos-publicacoes-insumos/2946 regras_analise_sementes.pdf

BRENHA, J.A.M.; OLIVEIRA, N.C.; CÂNDIDO, A.C.S.; GODOY, A.R.; ALVES, C.Z. Teste de tetrazólio em sementes de pinhão manso. Visão Acadêmica, v.13, n.4, p.63-79, 2012.

CHAMMA, H.M.C.P.; NOVEMBRE, A.D.L.C. Teste de tetrazólio para as sementes de milho: períodos de hidratação e de coloração das sementes. Revista Brasileira de Sementes, v.29, n.2, p.125-129, 2007. http://www.scielo.br/pdf/rbs/v29n2/v29n2a17 
CORDOVA-ALBORES, L.C.; ZAPOTITLA, E.S.; RÍOS, M.Y.; BARRERA-NECHA, L.L.; HERNÁNDEZ-LÓPEZ, M.; BAUTISTABAÑOS, S. Microscopic study of the morphology and metabolic activity of Fusarium oxysporum f. sp. gladioli treated with Jatropha curcas oil and derivatives. Journal of Microscopy and Ultrastructure, v.4, n.1, p.28-35, 2016. https://doi.org/10.1016/j.jmau.2015.10.004

DIAS, M.C.L.; SILVA, W.R. Determinação da viabilidade de sementes de café através do teste de tetrazólio. Pesquisa Agropecuária Brasileira, v.21, n.11, p.1139-1145, 1986.

MARCOS-FILHO, J. Fisiologia de sementes de plantas cultivadas. Londrina: ABRATES, 2015. 617p.

FRANÇA-NETO, J.B.; KRZYZANOWSKI, F.C.; COSTA, N.P. Metodologia do teste de tetrazólio em sementes de soja. In: KRZYZANOWSKI, F.C.; VIEIRA, R.D.; FRANÇA-NETO, J.B. (ed.). Vigor de sementes: conceitos e testes. Londrina: ABRATES, 1999. p.5-28.

GASPAR-OLIVEIRA, C.M.; MARTINS, C.C.; NAKAGAWA, J. Concentração da solução de tetrazólio e período de coloração do teste para sementes de mamoneira. Revista Brasileira de Sementes, v.31, n.3, p.38-47, 2009. http://dx.doi.org/10.1590/S0101-31222009000300004

GASPAR-OLIVEIRA, M.C.; MARTINS, C.; NAKAGAWA, J. Pré-condicionamento das sementes de mamoneira para o teste de tetrazólio. Acta Scientiarum Agronomy, v.33, n.2, p.303-311, 2011. 10.4025/actasciagron.v33i2.6025

GRABE, D.F. Measurement of seed vigor. Journal of Seed Technology, v.1, n.2, p.18-32, 1976. http://www.jstor.org/ stable/23430384?seq=1\#metadata_info_tab_contents

GRZYBOWSKI, C.R.S.; OHLSON, O.C.; SILVA, R.C.; PANOBIANCO, M. Viability of barley seeds by the tetrazolium test. Revista Brasileira de Sementes, v.34, n.1, p.47-54, 2012. http://dx.doi. org/10.1590/S0101-31222012000100006.

GÜBITZ, G.M.; MITTELBACH, M.; TRABI, M. Exploitation of the tropical oil seed plant Jatropha curcas L. Bioresource Technology, v.67, n.1, p.73-82, 1999. https://doi.org/10.1016/S09608524(99)00069-3

HU,P.; WU, L.; HOLLISTER, E.B.; WANG,A.S.; SOMENAHALLY, A.C.; HONS, F.M.; GENTRY, T.J. Fungal community structural and microbial functional pattern changes after soil amendments by oilseed meals of Jatropha curcas and Camelina sativa: a microcosm study. Frontiers in Microbiology, v.10, n.537, 2019. https://www. frontiersin.org/articles/10.3389/fmicb.2019.00537/full

KAK, A.; PANDEY, C.; GUPTA, V. Assessment of viability of Jatropha curcas L. seeds using the tetrazolium test. Seed Science and Technology, v.37, n.2, p.512-515, 2009. https://doi.org/10.15258/sst.2009.37.2.28

LAMARCA, E.V.; BARBEDO, C. J. Methodology of the tetrazolium test for assessing the viability of seeds of Eugenia brasiliensis Lam., Eugenia uniflora L. and Eugenia pyriformis Cambess. Journal of Seed Science, v.36, n.4, p.427-434, 2014. http://dx.doi. org/10.1590/2317-1545v36n41029

MAGUIRE, J.D. Speed of germination - aid in selection and evaluation for seedling emergence and vigor. Crop Science, v.2, n.2, p.176-177, 1962.
MAPA. Ministério da Agricultura, Pecuária e Abastecimento. Instrução Normativa $n^{\circ} 44$, de 22 de novembro de 2016. Oficializado o teste de tetrazólio na comercialização de sementes de forrageiras. http://www.agricultura.gov.br/assuntos/insumos-agropecuarios/ insumos-agricolas/sementes-e-mudas/publicacoes-sementes-emudas/INN44de22denovembrode2016.pdf

MEDEIROS, A.D.; ARAÚJO, J.O.; LEÓN, M.J.Z.; SILVA, L.J.; DIAS, D.C.F.S. Parameters based on x-ray images to assess the physical and physiological quality of Leucaena leucocephala seeds. Ciência e Agrotecnologia, v.42, n.6, p.643-652, 2018. http://dx.doi. org/10.1590/1413-70542018426023318

MOFIJUR, M.; MASJUKI, H.H.; KALAM, M.A.; ATABANI, A.E. Evaluation of biodiesel blending, engine performance and emissions characteristics of Jatropha curcas methyl ester: Malaysian perspective. Energy, v.55, p.879-887, 2013. https://doi.org/10.1016/j. energy.2013.02.059

OLIVEIRA, G.L.; DIAS, D.C.F.S.; HILST, P.C.; SILVA, L.J.; DIAS, L.A.S. Standard germination test in physic nut (Jatropha curcas L.) seeds. Journal of Seed Science, v.36, n.3, p.336-343, 2014. http:// dx.doi.org/10.1590/2317-1545v36n31015

PARAIISO, H.A.; BRANDÃO-JUNIOR, D.S.; AVELAR, R.I.S.; COSTA, C.A.; GOMES, L.S.P.; NASCIMENTO, W.M. Adjustments in the tetrazolium test methodology for assessing the physiological quality of chickpea seeds. Journal of Seed Science, v.41, n.1, p.7-12, 2019. http://dx.doi.org/10.1590/2317-1545v41n1187777

PEREIRA, D.F.; BUGATTI, P.H.; LOPES, F.M.; SOUZA, A.L.S.M.; SAITO, P.T.M. Contributing to agriculture by using soybean seed data from the tetrazolium test. Data in Brief, v.23, p.103652, 2019. https://doi.org/10.1016/j.dib.2018.12.090

PINTO, T.L.F.; MARCOS-FILHO, J.; FORTI, V.A.; CARVALHO, C.; GOMES-JUNIOR, F.G. Avaliação da viabilidade de sementes de pinhão manso pelos testes de tetrazólio e de raios-x. Revista Brasileira de Sementes, v.31, n.2, p.195-201, 2009. http://dx.doi. org/10.1590/S0101-31222009000200023

POMPELLI, M.F.; FERREIRA, D.T.R.G.; CAVALCANTE, P.G.S.; SALVADOR, T.L.; SHIUE HSIE, B.; ENDRES, L. Environmental influence on the physico-chemical and physiological properties of Jatropha curcas seeds. Australian Journal of Botany, v.58, n.6, p.421-427, 2010. https://doi.org/10.1071/BT10102

RAMPADARATH, S.; PUCHOOA, D.; JEEWON, R. Jatropha curcas L: phytochemical, antimicrobial and larvicidal properties. Asian Pacific Journal of Tropical Biomedicine, v.6, n.10, p.858-865, 2016. https://doi.org/10.1016/j.apjtb.2016.01.019

SANTOS, V.L.M.; BANCI, C.A.; CALIL, A.C.; MENDOZA, R.M.; SILVA, R.F.; SANTOS, C.M. Utilização do teste de tetrazólio na avaliação da germinação e do vigor de sementes de algodão (Gossypium hirsutum L.) como um teste complementar ao teste padrão de germinação. Revista Brasileira de Sementes, v.14, n.2, p.155-159, 1992.

SCHULZ, D.G.; SCHNEIDER, C.F.; BRAND, F.C.G.; MALAVASI, U.C.; MALAVASI, M.M. Avaliação de danos causados por percevejos em sementes de Jatropha curcas. Pesquisa Florestal Brasileira, v.32, n.71, p.335-339, 2012. https://pfb.cnpf.embrapa.br/ pfb/index.php/pfb/article/view/330/0 